\title{
Representations of Woman's Body in Prose by Latvian Women Writers
}

\author{
Zita Kārkla \\ Doctoral student, University of Latvia \\ zitakarkla@msn.com
}

\section{Doi:10.5901/ajis.2013.v2n8p397}

\begin{abstract}
Feminism has been deeply concerned with female body either as something to be rejected in the pursuit of intellectual equality or as something to be reclaimed as the very essence of women. Another alternative, associated with feminist postmodernism, seeks to emphasize the importance and inescapability of embodiment rather as a differential and fluid construct than as a fixed given. Different female body representations are inscribed in Latvian women's prose from 1960s to 2010. As it was common for Soviet literature, also in prose of Latvian women writers of the period body and sexuality, especially the female one, was left beyond the discussion, mostly figuring as the unspoken. If woman's body was inscribed in texts by Latvian women writers of the Soviet period, then either as an object of man's desire or in connection with woman's reproductive function as mother's body. However, in the end of 1980s with the disappearance of the censorship and the changes in the general cultural atmosphere, in prose of Latvian women writers previously repressed issues of women's lives started to appear and woman's body was recovered; a different women's history was told through inscriptions on female bodies. In contemporary Latvian women's prose woman's body appears as essential part of female identity, emphasizing inseparability of body and mind and acknowledging that woman experiences the world also with her body.
\end{abstract}

Keywords: Latvian women's prose, woman's body, mother's body, women's history

\section{Introduction}

Feminist scholar Elizabeth Grosz in her work Volatile Bodies demonstrates that sexually specific body is socially constructed and somehow in Western culture women have always been perceived as "more biological, more corporeal, and more natural than men" (Grosz 1994, 14). Feminist theories have searched for new ways of talking and writing about woman's body. Considering that in dominant Western cultural tradition body has been perceived as material and constant given, fixed biological unity that has to be transcended in order to free the mind, it is essential to look at body avoiding biological, essential and universal presumptions and to emphasize the importance and inescapability of body as different and fluid rather than as a fixed given, meaning, that there are many different bodies that are not only marked by sex, but also by race, class, sexuality, age, etc. and none of those factors is more important then the others. Recognizing that there are several and fluid embodiment possibilities, body becomes a place for seeking. The aim of the paper is to analyze what female body representations can be found and what changes concerning those representations can be observed in the prose by Latvian women writers during the time period from 1960s to 2010.

\section{Female body in Prose of Soviet period}

As it was common for Soviet literature, also in prose by Latvian women writers of the period body and sexuality, especially the female one, was excluded from texts. Blame and shame was placed on the body in the attitudes that dominated in the society and culture of the time. As women writer Rudite Kalpina in her novel Man for Lies, Flattery and Pleasures (1993) writes: "(...) human figures in the school anatomy book convincingly confirmed that for a Soviet person sexual differentiation did not exist, because both for men and women in the according places there was - nothing. One big nothing for all." (Kalpina 1993) And if woman's body was inscribed in texts by women writers of the Soviet period, then either as an object of man's desire or in connection with woman's reproductive function as mother's body. 
Writer Ilze Indrāne's ${ }^{1}$ novel Watercarrier (1977) is a story about woman named Klinta. Indrāne also inscribes Klinta's body in the text both as an object of her husband's desire and in connection with her reproductive function as mother's body. Indrāne describes the first sexual intercourse between Klinta and her husband as seen from Klinta's point of view:

Somewhere far, far in the corner of the living room sprawls rust colored sofa. There are no blankets, no sheets. Doesn't matter. Doesn't matter! Let it be over with faster. Then she could close her eyes and forget about her terrible, powerless nakedness in the middle of an unknown room. (Indrāne 1977, 31)

The shame about her nakedness that Klinta feels can be associated with the fact that a woman looks at her body through the eyes of a man. A similar situation is described in Andra Neiburga's ${ }^{2}$ story Stuffed Birds and Birds in Cages (1987) when a woman is overwhelmed with shame about her body after a sexual intercourse: "In this room there are so many things that don't belong to either Dainis or me that I am seized with shame about my nakedness and about what we both just did a minute ago. In front of everyone." (Neiburga 1987, 164) 'Everyone' in this case means things belonging to roommates in the dormitory room that Dainis shares with some other young men. Feminist philosopher Sandra Lee Bartky had pointed out that woman lives her body enveloped by gaze of anonymous patriarchal Other (Bartky 2001, 129). Woman's body in prose by Latvian women writers during Soviet era is also inscribed through the gaze of man. Feminist scholar Sandra Gubar writes that women "are products of the male imagination, objects created for the use of men." (Gubar 1985, 293) In Regina Ezera's ${ }^{3}$ story Reflection of the Sun (1969) Elza's body is inscribed in the text as it is seen from her husband Žanis pont of view and that is also how Elza looks at her body, as if through her husband's eyes:

Was it a pitty and despise that she earlier caught in Žani's gaze at the door? It hurts; however, she must look the truth in the eye. Slowly but at the same time unavoidably she has changed and not for the good, she has gained weight (and Žanis had never liked fat women!), her hair is like flax - neither light, nor dark (maybe colour the hair?), and double chin has appeared. (Ezera 1969, 120)

Elza criticizes her body because she wants to be desirable in her husband's eyes. Thus the texts by Latvian women writers of the Soviet period reflect the traditional order where woman, associated with the body that is subordinated to the mind, is situated in the prison of her own body and man's desire. Both Klinta in Indrāne's novel and Elza in Ezera's novel represent Nature to their husbands. Although Klinta is a talanted pianist and Elza had aspired to become an artist, for their husbands they are pure bodies. When Elza's husband watches her making little meat pies in kitchen, he wonders to himself: "Is she still fooling around with clay in secret, or has she got over it for good?" (Ezera $1969,186)$ Although he doesn't say it out loud, his attitude is negative, while Elza's older woman friend Guna insists that Elza should keep up with her art, encouraging her not to cut all ties with her earlier aspirations. When Elza replays: "That's not art. Anybody can do it," Guna asks: "And what kind of arts are you busy with now? In the kitchen? Or in bed?" (Ezera 1969,186)

Simone de Beavoir in her work The Second Sex focuses on the way women have been made into man's other, describing how "one is not born but becomes a woman" through changes in women's bodies that prepare them for maternity (De Beavoir 1969). De Beavoir also calls upon literary work by men in order to show that for men woman represents Nature and either assures through opposition or threatens by temptation his intellectual activity; using examples of works by women writers de Beavoir shows that such women's experience of their bodies as the pain and disgust makes them regard their bodies as alienating, "something other than herself" (De Beavoir, 1969). Woman's body in Latvian women's prose is also conceptualized as maternal - feminine. In Indrāne's novel Watercarrier, Klinta's feeling of shame about her naked body after the first sexual intercourse with her husband is followed by happiness that now she will be able to become a mother. Indrāne describes it as a bodily feeling:

\footnotetext{
1 Ilze Indrāne (1927), writer and teacher, published short stories, novels, plays since 1959. Indrāne earned the title of Distinguished Culture Worker of the Latvian Socialist Republic in 1974.

${ }^{2}$ Andra Neiburga's (1957) prose has been published since 1985, and critics and also wider readership consider her to be one of most gifted representatives of Latvian contemporary literature. Neiburga has received the Annual Prize for Culture awarded by the leading Latvian newspaper "Diena" for her latest book "Push, push" (2004).

${ }^{3}$ Regīna Ezera (1930-2002) was one of the most outstanding Latvian prose writers of the 20th century. The author of more than twenty books, she wrote both novels and stories to equally high acclaim. Ezera earned the title of Distinguished Culture Worker of the Latvian Socialist Republic in 1974 and she became Latvia's People's Writer in 1981.
} 
Still a happy heaviness didn't allow Klinta to move even her eyelids. In silence without a breath wishing to melt in sounds and colors belonging to her that she had never felt before. As if that child already alive and warm and heavy slept in her body. As if little lips already sucked at her breast. (Indrāne 1977)

Although it is too early to feel any signs of pregnancy in her body, Klinta's bodily experience in the text is concentrated on woman's experience of her body as maternal body.

Also Ezera in her prose inscribes woman's bodily experience in connection to mother's body. However, in the story Reflection of the Sun even pregnancy in connection to woman's body is shown as a subject that is silenced in the culture of the time. When Elza's older friend Guna asks her if she is pregnant: "Elza notices that she blushes. Heat flows over her face and neck, her ears are on fire. She bows her head. The kitchen table is covered with blue oilcloth - yellow dots on blue background that is worn out along the folding lines. - No, aunt Guna." (Ezera 1969, 158) Although two women in the story share a close friendship, talking about their bodies in this aspect is a taboo as defined by the culture.

The main protagonist Laura's feelings in Ezera's novel The Well (1972) that are connected to childbirth are compared to "moments of white enlightenment" and signals a new awareness of her own body:

Maybe Laura's share of happiness was modest if looking back at her life as the highest points she saw the days that her children were born? Those were the moments of great, white enlightenment that nature has given only to women as a reward for all that only she must suffer. She lay there heavy as earth after the thunderstorm and couldn't move her limbs, every muscle ached in her overstrained body, but in her ears as a miracle the sound of child's feeble, dim voice filled up her whole world. (Ezera 1972)

In this quotation Ezera expresses positive attitude towards woman's experience of becoming a mother. This attitude repeatedly appears in her work celebrating motherhood. However in Ezera's prose woman's bodily experience of pregnancy, childbirth, lactation is connected to her psyche, and while for one woman giving birth is the most fulfilling and happiest moment of her life, in the story collection By Quiet Waters (1987), Ezera inscribes different attitudes where women are thinking about their pregnant bodies as reproduction machines. Zita, one of the protagonists thinks: "And wasn't my body now only a vessel for another life that resided in me?" (Ezera 1987) Dace, another woman protagonist, in a different story by Ezera shares similar feelings. When she becomes pregnant her lover leaves her and because of that she decides to give her child to her sister who can't have children of her own:

(.) I had become used to the thought that I will give birth to Livija's child. That I am a machine, a device that has to perform a prescribed function. (..) I stayed in Smiltene until the end of my maternity leave. When I went back to Riga by bus, milk strongly leaked from me. Good it was winter. I wrapped in coat. And suddenly I bursted in tears. (Ezera 1987, 174)

There are two possible explanations for the changes in representation of mother's body in the cited examples. First, Ezera's story collection By Quiet Waters is published in 1987 when the general cultural atmosphere in Latvia was changing allowing writers to explore previously tabooed themes; and second, women's bodily experiences are shown as closely connected with women's psyches, and thus woman's body and mind appears as inseparable.

\section{Woman's Body and Woman's Desire}

In the end of the 1980s, with the disappearance of the censorship and the changes in the general cultural atmosphere, in prose of Latvian women writers previously repressed issues of women's lives started to appear and also woman's body was recovered. In the 1980s also a new generation of Latvian women writers - Andra Neiburga, Gundega Repše, Rudīte Kalpiņa, Aija Vālodze, Eva Rubene and others - started to publish. Despite their differences, they were grouped under a name 'new wave' or 'young angry girls' because they turned against obligatory optimism and didactics that dominated in prose of the time. Instead in their texts they draw attention to such themes as loneliness, absurdity of life, also sex, etc., themes that previously were excluded from Soviet literature. Silenced aspects of women's experiences started to appear in prose by Latvian women writers and woman's body obtained new representations in text. The myth about 'bright future' or obligatory optimism that functioned in literature of the Soviet period completely excluded from literature a wide area of themes, including erotic depictions of the body (Berelis 1999). Neiburga in the short story Stuffed Birds and Birds in Cages (1987) besides describing young woman's feelings of shame about her naked body in her boyfriends dormitory room (mentioned earlier as an example of woman living her body enevoped by the male gaze) also allows different representation of woman's body inscribing woman's physical sensations that express woman's sexual pleasure: 
And I answer to his kisses and forget about everything else in the world. There is only Dainis, his arms, mouth, his teeth against my teeth, his arms on my breasts, his arms on my belly, taste of blood, his arms - everywhere; the weight of his body that presses me and - strangely - carries me, and light, there is so much light, all my life from now on will be in the circle of this light, and I scream from happiness together with my body... (Neiburga 1987, 163)

In this passage Neiburga inscribes woman's bodily experience in connection with woman's desire that French feminists, a group of women who promoted a new approach to thinking about women, their bodies and their desires in 1970s write, emphasizing desire and the body, women's erogenous zones and the possibilities of unleashing their libidinal force in writing (Weil 2006). For French feminists women's desire is what is most repressed and oppressed in the society and because of that - woman's desire is what most needs to find the expression.

French feminist, philosopher and linguist Luce Irigaray and French feminist writer Helene Cixous emphasize that women, historically limited to being sexual objects for men (virgins or prostitutes, wives or mothers), have been prevented from expressing their sexuality in itself or for themselves. Talking about their bodies and sexual pleasure that have been so absent or so misrepresented in male discourse, could be the starting point for women to know and represent themselves (Jones 1985). Irigaray writes that if women are to discover and express who they are, they must begin with their sexuality, and their sexuality begins with their bodies, with their genital and libidinal difference from men (Jones 1985). Begining with the 1980s Latvian women writers started seeking new ways of exploring women's bodily experiences in their texts, including woman's desire and woman's sexuality as expressed by women themselves for themselves.

Inga Ābele 4 in her story Truths of the Bath-house (2004) describes women's naked bodies in the bath-house adolescent girls, young and old women. Women's bath-house is a place where shame about nakedness doesn't appear and writer shows women's bodies the way they are, accepting and valorizing their physical differences. Story's protagonist, a young woman named llze reveals that the public bath-house for her as an adolescent girl was a place where to find out things about woman's body. Ilze's experience emphasizes cultural situation growing up in Soviet Latvia with female body excluded from both public and private discussion - in school anatomy books human figures are drawn without any indications of their sex and also in Ilze's conversations with her mother body and its functions is a taboo theme, thus the bath - house becames the only place where Ilze can learn something about her own body. When Ilze tries to ask questions to her mother concerning her first menstruation, the mother avoids talking about the subject: "Why we, women, have it and how to use tampons, she couldn't tell that. That's why in the bath-house I kept my eyes and ears open. I was looking at breasts, hips, girls, adolescents, women, old women. Like at encyclopedia." (Ābele 2004, 270) Thus Ābele in her story reveals the attitudes about female body that dominated in the society, but simultaneously she also offers the silenced story, Ilze's lived experience in her body.

Ābele also inscribes woman's body in connection with her desire in the story, first, by describing erogenous zones of woman's body as naturally beautiful: "They had beautiful, dark vaginas with accurately folded lips like volcanos or dark blue plums. And their pussy hair glowed like silk, fawn-colored and thick." (Āble 2004, 271) Second, Ābele in her story inscribes female body in the connection with female desire and pleasure. Ilze admires three middle-aged women that she sees in the bath-house every Friday. Ilze characterizes those women as sensually and sexually liberated, those are the women that in her eyes symbolize the plentifulness and completeness based on what she had observed looking at their bodies and overhearing their conversations when the three women share with one another their experiences of orgasms:

But no one knows that with nobody else in the bed I had felt as good as with him. (..) I can't describe it to you in words, how it is, but there is the feeling - like I was a goldfish that has been catched on the hook and could die from pleasure. (..) How could one refuse such a pleasure being in their right mind? (Ābele 2004, 172)

Ilze knows nothing more about the women whose conversations she absorbs in the bath-house every friday, the only and the most important thing that stands out to her is the way those women feel about their bodies - embracing their bodily experiences and celebrating them.

Also Nora Ikstena ${ }^{5}$ in her prose seeks the language for women's corporeal experiences, which have been silenced

\footnotetext{
4 Inga Ābele (1972) writer of prose, drama and poetry. Ābele has received a number of literary awards: the story collection "Observations in the Time of Snow" was awarded the Annual Prize for Literature in 2004, her novel "High Tide" received two prizes, the Annual Literature Prize and the Baltic Assembly Prize for Literature in 2008.

${ }^{5}$ Nora Ikstena (1969) is the author of biographies, novels, collections of short stories and essays. The novel "The Education of the Virgin" (2001) was awarded with the Latvian Annual Prize for Literature in 2001. In co-operation with poet Imants Ziedonis, she published 
by the culture of the past. In her novel Amour Fou (2009) she re- imagines and re-articulates female body in order to enable women to both feel and think differently about their embodied form: "When God created the first female and didn't know after what likeness to form her down, in the woods, parting the grass he noticed the lace of delicate cantarellas. And he succeeded." (Ikstena 2009, 162) Ikstena poetically describes woman's erogenous zones as naturally beautiful.

'Joissance,' the French word for orgasm or for pleasure so intense that it is once of the body and outside it describes woman' pleasure which is outside language:

By raising issues of desire and body, French feminism finds deception at the base of the great, Western intellectual traditions which presume to derive truth from the mind as separate from the body. In fact, the body must be seen as contributing the very condition for tought. (Weil 2006, 154)

Ikstena in the novel Amour Fou creates an imaginary place - fields of 'orgaismas' (the word Ikstena has created is made up from two words: orgasm+light) where orgasms that humans experience in their bodies are grown and harvested as fruit, thus speaking about bodily experience that simultaneously is of the body and outside of it. Fields of 'orgaismas' is a place outside the body, a place that resembles paradise and that humans can access only for seconds - the duration of an orgasm:

Ada doesn't believe her vagina, because in Amo's arms the whole night all around her breaks, brawls and glows galactics of 'orgaismas'. (..) first they come in little waves, climbing from ankles to her ear lobes, then lightly shivering slide back. Then they start rising in waves - melt, flow, disappear, make Ada into fluttering substance. (Ikstena 2009, 110)

Ada's relationship with Amo is relationship based on bodily pleasure; it is a bodily encounter that helps her to forget love, betrayal and pain of her previous relationship. Ikstena inscribes woman's desire and sexuality showing how Ada yearns for bodily pleasure with another man inspite of the pain that she feels about the lost relationship. However, at the same time lkstena also inscribes the inseparability of physical and psychological experience:

This is the cradle of her 'orgaismas'. When it is stirred, the stars, galactics and planets move with it. The soul is silent, but everything else is put in motion. (..) Is it possible that her body and spirit are separated in this bed? Ivs lives in her soul, she lives everything else excluding her soul. She can touch everything else, she can bring everything else close to her, very close to the bliss. Except the soul. (Ikstena 2009, 134)

Woman's sexual pleasure and desire is very important in the novel, however, Ikstena inscribes it as incomplete without the emotional tie. What is important about Ikstena's novel Amour fou is that she voices not only woman's sexuality as an organic part of woman's identity but also inscribes in the texts woman's desire for relationship with a man where emotional and physical aspects are equaly important.

\section{Woman's Body and Women's History}

Nora Ikstena in her prose creates a female world. Concerned with the journey towards the meaning of life she searches for it in her short stories, biographies and novels. In novels A Celebration of Life (1998) and The Education of the Virgin (2001) Ikstena focuses on women's experiences also telling women's history through women's bodily experiences abortions, rape, pregnancy, post- partum depression, suicide. In the novel A Celebration of Life Ikstena inscribes women in Latvian history of the $20^{\text {th }}$ century through woman's body: women have to sell their bodies in order to liveduring the wartime and in deportation in Siberia, they get pregnant and undergo abortions, they intoxicate in order to forget the absurdity of life. Eleonora is a deportee in Siberia where body has no value and "with unceasing feeling of hunger she had inherited some terrifying feeling of freedom - that everything is allowed if only one gets food for it." (Ikstena 2001, 88) In the novel The Education of the Virgin Ārija, as a new wife in Latvia in the 1930s, experiences seven abortions in her body because her husband decides that: "Children don't suit to young, wealthy Latvians (..) but with preservatives he always messes up something." (Ikstena 2001, 67) The painful experience of many abortions invades both her body and her soul: "Illegal doctor gives small, white pills to Jukija, waits for ten minutes and starts working. Jukija bites her lips to

a biographical work of fiction "The Indefinite Was" (2006), an attempt at reconstructing his childhood memories. For The Indefinite Was Ikstena received the most prestigious literary award of the Baltic states - the Baltic Assembly Prize, the Latvian Annual Prize for Literature, and the Annual Prize for Culture of daily newspaper Diena. 
blood -unbearable, insane pain. The fruit is scratched out from the alive body as seeds from a cucamber." (Ikstena 2001, 78) Life from woman's body is brutaly removed with "hell's instrument" and afterwords she experiences unbearable pain and guilt that tears both her body and her soul.

Ikstena in the novel also inscribes woman's experience giving birth during the wartime: "Happily Jukija gives birth to daughter in the cold war hospital where glass from the windows had been broken after bombing. Happily she lies in her dried up blood. (..) Happily from her breasts will flow lots of milk."(Ikstena 2001, 106) Ārija/Jukija in the war hospital gives birth to her daughter Astrīda who later becomes a 'women's doctor', and a vast squadron of rural women sits patiently in a row by the door of her cubbyhole, quietly waiting their turn to tell the lady doctor the tales of woe of their bodies and their souls. ... legal, backstreet, spontaneous abortions, premature births, ectipic pregnancies, ovarian infection, slipped wombs, coiti interrupti, trichomonosis, cysts, irregular menstrual cycles, ovarian cancer, climaxis hystericalis, cervical cancer, induced labour, healthy preganancy, Caesarean section, difficult pregnancy, forceps, pre-partum depression, post-partum depression, hysterical womb, frigidity, onset of ovulation, absence of ovulation, painful menses, trush... (Ikstena 2002, 15 - 16)

Again, body and soul tell the shared story, because in Ikstena's prose stories of body and soul are inseparable.

Gundega Repše ${ }^{6}$ in novel Thumbelina (2001) also writes women's history, Latvian history of the $20^{\text {th }}$ century that women have experienced in their bodies. In the story of Amelia Repše inscribes womans experience in deportation in Siberia - hunger, cold, hard work, but also pregnancy and childbirth:

How was Jukums born? Māk was holding petroleum lamp so that the midwife could see him in the darkness of the night. It was an old wise woman, midwife couldn't help me much. I was in labour for two days, so worn out that in the end Māk run to get a different wise woman - a wiser one. From a higher category. She then chanted in Russian something about gates of heaven or paradise that has to open, pushed and soon afterwards Jukums was there. (Repše 2001, 120)

Thus different experiences of female bodies are inscribed in connection to lived women's history in Latvian women's prose. One part of the story is told through violence, rape, abortion, and disease, however, there is also a more positive side of women's history as experienced in their bodies, that in the prose of women writers is told through the childbirth.

\section{Woman Writer: Her Body and Her Text}

Inga Ābele writes: "I know only that what I feel. (..) So I have come to the conclusion that, in my case, woman in the beginning had dwelled in the text, then this text had re-created the world around her, and in this world now lives the woman and the texts lives in her." (Ābele 2003, 11) Ābele has also written a work of documental prose To the East of the Sun, to the North of the Earth (2006) in the form of diary entires that speaks about her living in her text. In this work she is so honest and so open that she becomes vulnerable, not being afraid of revealing an image that would not correspond to the one of an acknowledged writer. Later in an interview Âbele about this work would admitt that there it is impossible to talk about a literary ' $I$ ' in this text, because it is herself and her lived experience (Repše 2012, 101). Susan Gubar had written: "For the artist, the sense that she is herself the text means that there is little distance between her life and her art, and "the attraction of women writers to personal forms of expression like letters, autobiographies, confessional poetry, diaries, and journals points up the effect of a life experienced as an art or an art experienced as a kind of life (..)" (Gubar 1985, 299). Helene Cixous emphasizing the connection between woman's body and women's writing had written: „Woman must write her self: must write about women and bring women to writing, from which they have been drived away as violently as from their bodies ... Woman must put herself into the text - as into the world and into history - by her own movement..." (Jones 1985b, 85). In many prose texts of Latvian women writers the distance between writer's own experience and her text is diminished, meaning that Latvian women writers experience their bodies as available medium for their art.

Nora Ikstena has said that actually all the literature is about our experience connected to the three most important concepts: life, death and love. Ikstena's story Still Life withDeath (2004) is a story about mother - daughter relationship written from daughter's perspective whose mentally ill mother chokes on a piece of bread and almost dies on her arms.

\footnotetext{
${ }^{6}$ Gundega Repše (1960), writer and art scholar, publishes prose since 1979. Repše writes novels, short stories, and essays and is also a literary critic, an art critic and a columnist. In the nineties she became one of the most brilliant writers of contemporary Latvian prose. Received the Annual Award for Literature, Latvia's most prestigious literary award in 2000.
} 
Ikstena in the letter to her friend and literary mentor, writer Dzintars Sodums tells about a similar incident in her own experience: „My mother almost smothered in the arms of my father and I, but in some miraculous way we were able to respire her. Now she partly lives at home and partly in Tvaika Street, that's how mad house is called here." (Ceplis 2007, 31) Ikstena in the story Still Life with Death has recreated her own experience into prose, and in another letter to Sodums she writes: „You are right - if one writes what one knows, has experienced, then there is no need to hide behind invented corners. Although I must say that I had more joyfull heart when I was writing my „pluktvaserus” (light water), not the "groundwaters"." (Ceplis 2007, 31)

In Regīna Ezera's novels Smouldering Fire (1977), Violence (1982), and Betrayal (1984) dominate such forms of writing as forewords, notes, letters, diaries, reflections, and fragments. The novel Betrayal is comprised of the Author's letters to Irēna, a young aspiring woman author, and excerpts from the Author's diaries. Ezera in the novel has included prototypes and themes from her own experience including painful events in her life, but the main theme of the novel is the struggle to find a balance between motherhood and artistry: "Must I be deeply ashamed that I am not an ideal wife because for the ideal wife children come first, while for me, I'm afraid (why do I write "I'm afraid"?), in the first place is my "work" (why do I put it in quotation marks?)" (Ezera 1984, 223) This confession corresponds to Ezera's own experience as Ikstena in her biographical work about writer Ezera Being with Regina (2007) writes:

Thirty eight years young Regina during the day had finished her duties at home (..) in the evening she closes the cell door behind her. Here everything belongs only to her - her notes, the book shelf, typewriter (..) so young she already has had so much - two husbands, three children. Full - time writer's life - publications, books, gatherings, meetings with readers. Full - time family budget life - she is the main earner. Full - time home life - cleaning, cooking, ironing, washing, sewing, taking care of, weeding, preserving etc. (Ikstena 2007, 40)

Thus the Author's voice in Ezera's novel Betrayal conveys her lived experience. However, Ezera doesn't give the Author a name in that way also generalizing woman writer's experience.

Woman's attitude towards her body is influenced by historical, social and cultural contexts, and also in literary representations woman's body appears as changing. During the Soviet era in prose by Latvian women writer's woman's body mostly figures as the unspoken or is inscribed as the object of man's desire and maternal body. Because of this perception woman's body is mostly regarded as inherent limitation on women's capacity for equality and woman is situated in the prison of her own body and man's desire. However, the situation changes in the 1980s, when the new generation of women writers started to publish. Until 1989 in Latvia (as in the entire Soviet Union) censorship was imposed influencing both the subject matter and the means of representation. With the disappearance of the censorship and the changes in the general cultural atmosphere, it became important to reveal in writing that which was left unspoken, to represent "the dark sides" of the life. In the prose of Latvian women writers previously repressed issues of women's lives appeared and woman's body was recovered. Female suffering as inscribed on their bodies: violence, rape, abortion, and disease - was revealed in prose and women's history was told through those inscription on female bodies. In contemporaray Latvian women's prose woman's body is inscribed as essential part of female identity. Body and mind are not separated, addmitting that woman perceives the world also with her body. There is also a connection between woman's body and woman's creativity as Latvian women writers sometimes experience their bodies and their lived experiences as available medium for their art and in those cases the distance between the woman writer and her text is often radically diminished.

\section{Ackonwledgement}

This work has been supported by the European Social Fund within the project «Support for Doctoral Studies at University of Latvia».

\section{References}

Ābele I. (2003). Kad dzirdu šos divus vārdus kopā - sieviete tekstā ... Feministica Lettica Rīga: LU, 2003, pp. 9 - 11.

Ābele, I. (2004). Sniega laika piezīmes. Rĩga: Atēna.

Beavoir, de S. (1969). The Second Sex. London: The New English Library Books.

Bartky, S. (2001). Fuko sievišǩība un patriarhālās varas modernizācija. Mūsdienu feministiskās teorijas. ed. Novikova, I., Rīga: Jumava, pp. 198 - 219.

Berelis, G. (1999). Latviešu literatūras vēsture. Rīga: Zvaigzne ABC.

Ceplis. R. (2007) Rakstnieki par mūsdienu latviešu literatūru: Dzintara Soduma sarakste ar Noru Ikstenu Platforma Nr. 3. Rīga: LU, pp. 
$67-89$.

Ezera, R. (1969). Saules atspulgs. Rīga: Liesma.

Ezera, R. (1972). Aka Rīga: Liesma.

Ezera, R. (1984). Nodevība Rīga: Liesma.

Ezera, R. (1987). Pie klusiem ūdeniem. Rīga: Liesma.

Grosz, E. (1994). Volatile Bodies. Toward a Corporeal Feminism. Bloomington and Indianapolis: Indiana University Press.

Gubar, S. (1985). The Blank Page and Female Creativity. The New Feminist Criticism. Essays on Women, Literature and Theory. E. Showalter, ed. New York: Pantheon Books, pp. 292 - 314.

Ikstena, N. (2001). Jaunavas mācība. Rīga: Atēna.

Ikstena, N. (2007). Esamība ar Regīnu. Rīga: Dienas grāmata.

Ikstena, N. (2009). Amour Fou. Rīga: Dienas grāmata.

Indrāne, I. (1977). Ūdensnesējs. Rīga: Liesma.

Jones, A. R. (1985). Writing the Body. Toward an Understanding of l'Ecriture feminine. The New Feminist Criticism. Essays on Women, Literature and Theory. E. Showalter, ed. New York: Pantheon Books, pp. 361 - 379.

Jones, A. R. (1985). Inscribing femininity: French theories of the feminine. Making a Difference. Feminist Literary Criticism, pp. $80-113$.

Kalpiņa, R. (1993). Vîrietis meliem, galimiem, izpriecām. Rīga: Livonija 4

Neiburga, A. (1987). Izbāzti putni un putni būros. Rīga: Liesma.

Repše, G. (2000). İkstīte. Rīga: Pētergailis.

Repše, G. (2012). Rakstnieki Ir. Gadsimta sākuma skatiens. Rīga: Dienas grāmata.

Rubess, B. (2002). The Education of Nora Ikstena: An Introduction. Latvian Literature. Spring/summer, Rīga: Atēna, pp. 12 - 22.

Weil, K. (2006). French feminism's ecriture feminine. The Cambridge Companion to Feminist Literary Theory. Rooney, E., ed., pp. 153. 172. 